\title{
PENERAPAN GOOGLE DRIVE SEBAGAI MEDIA PEMBELAJARAN FISIKA DENGAN MENGGUNAKAN MODEL BLENDED POE2WE
}

\author{
${ }^{1}$ Heri Maulana Sidik, ${ }^{2}$ Nana \\ Pendidikan Fisika, Universitas Siliwangi, Tasikmalaya, Indonesia \\ E-mail : heri.mas360@gmail.com
}

\begin{abstract}
This research is a form of application of Google Drive in Physics learning media in the form of applications and the web that provides storage services and access documents and data online (distance) in learning. The objectives of this study are: 1) knowing how well Google Drive is as a physics learning media, and 2) knowing the effectiveness of learning through Google Drive as a physics learning media. The topic chosen in this research is physics learning media. This research uses a descriptive method with a qualitative approach obtained through literature study. Literature study here is intended through the study of some literacy, such as literacy literacy, scientific literacy and digital literacy. As for the object of this research is the Google Drive media as a new perception in physics learning media. So, the application of Google Drive as a Physics Learning Media using the POE2WE Blended Model, 1) Utilization of Google Drive as a Physics learning media is very good, especially when applied using the Blended POE2WE model; 2) The effectiveness of Google Drive in distance learning is very helpful for teachers and students who have obstacles or are in a variety of busy activities, especially teachers who are often out of town on state assignments. So, Google Drive is very effective and efficient.
\end{abstract}

Keywords: Google Drive, Physics Learning Media, Blended POE2WE Model.

\begin{abstract}
Abstrak
Penelitian ini merupakan bentuk penerapan Google Drive dalam media pembelajaran Fisika berupa aplikasi dan web yang menyediakan layanan penyimpanan dan akses dokumen dan data online (jarak jauh) dalam pembelajaran. Tujuan penelitian ini adalah: 1) mengetahui seberapa baiknya Google Drive sebagai media pembelajaran Fisika, dan 2) mengetahui keefektifan pembelajaran melalui Google Drive sebagai media pembelajaran Fisika. Topik yang dipilih dalam penelitian ini adalah media pembelajaran Fisika. Penelitian ini menggunakan metode deskriptif dengan pendekatan kualitatif yang didapatkan melalui studi pustaka. Studi pustaka disini dimaksudkan melalui penelaahan beberapa literasi, seperti literasi baca tulis, literasi sains dan literasi digital. Sedangkan untuk objek penelitian ini adalah media Google Drive sebagai persepsi baru dalam media pembelajaran Fisika. Jadi, penerapan Google Drive sebagai Media Pembelajaran Fisika menggunakan Model Blended POE2WE ini, 1) Pemanfaatan Google Drive sebagai media pembelajaran Fisika ini sangatlah baik, apalagi bila diterapkan dengan menggunakan model Blended POE2WE; 2) Keefektifan Google Drive dalam pembelajaran jarak jauh ini sangatlah mebantu bagi guru dan peserta
\end{abstract}


didik yang mempunyai kendala atau berada dalam berbagai kesibukan, apalagi guru yang sering keluar kota dalam tugas negara. Sehingga, Google Drive ini sangatlah efektif dan efisien.

Kata Kunci: Google Drive, Media Pembelejaran Fisika, Model Blended POE2WE.

\section{PENDAHULUAN}

Perkembangan dunia pendidikan di era revolusi industri 4.0 ini acapkali bertumbuh sangat pesat. Dimulai dari kurikulum, silabus, model, metode hingga media pembelajaran pun dikembangkan sedemikian rupa. Dari konvensional diubah drastis menjadi lebih up to date terhadap perkembangan teknologi informasi. Disisipkan berbagai macam hal, seperti pembelajaran jarak jauh menggunakan metode e-learning sampai dengan kursus online yang berhamparan di jejaring sosial media. Hal tersebut ditujukan untuk merombak pandangan pendidikan yang selalu tertinggal dengan hiburan. Jejaring sosial media menjadi ramai digunakan untuk aktivitas pembelajaran secara awan (online). Tidak hanya hiburan saja yang bisa banyak diminati oleh semua kaum dalam penggunaan internet, tetapi pendidikan pun sudah bisa diakses dengan mudah untuk memperlancar kegiatan belajar mengajar, baik itu di sekolah (kampus) maupun di masyarakat. Menurut Hasbullah (dalam Djamaluddin, 2014) menjelaskan bahwa dalam arti sederhana pendidikan sering kali diartikan sebagai usaha manusia untuk membina kepribadiannya sesuai dengan nilai-nilai di dalam masyarakat dan kebudayaannya. Dalam perkembangannya, istilah pendidikan atau paedagogic berarti bimbingan atau pertolongan yang diberikan secara sengaja oleh orang dewasa agar menjadi dewasa. Selanjutnya, pendidikan diartikan sebagai usaha yang dijalankan oleh seseorang atau kelompok orang lain agar menjadi dewasa atau mencapai tingkat hidup atau penghidupan yang lebih tinggi dalam arti mental.
Kemudian, Menurut Cahyono (2013) menyatakan bahwa Google Drive merupakan media penyimpan yang bisa dihandalkan, sehingga kita tidak akan kesulitan apabila datadata penting kita tertinggal atau hilang, kita masih bisa menggunkanan data/file tersebut dengan mengambilnya di aplikasi Google Drive, persyaratannya hanyalah ada sambungan internet.

Menurut Cahyono (2013) menjelaskan bahwa Google Drive sebagai media penyimpan di cloud yang disokong oleh Google, dimana sekarang ini Google merupakan perusahaan yang sangat besar bahkan bisa dikatakan sebagai perusahaan nomor satudalam pelayanan internet. Terlebih aplikasi ini akan dibuat untuk bisa dipakai pada lintas platform system operasi yang banyak digunakan sekarang ini, seperti pada Windows, Machintos, kemudian pada system operasi yang dipakai di handset seperti : Android, dan IOs. Sehingga dengan dapat dipergunakan pada bermacam-macam platform system operasi baik untuk laptop maupun handset, maka kita sudah tidak perlu kawatir lagi apabila kita berganti system operasi maka tidak akan bisa lagi menggunakan aplikasi ini.

Menurut Depdiknas (2003) dalam Muhson (2010) istilah media berasal dari bahasa Latin yang merupakan bentuk jamak dari "medium" yang secara harafiah berarti perantara atau pengantar. Makna umumnya adalah segala sesuatu yang dapat menyalurkan informasi dari sumber informasi kepada penerima informasi. Proses belajar mengajar pada dasarnya juga merupakan 
proses komunikasi, sehingga media yang digunakan dalam pembelajaran disebut media pembelajaran. Media pembelajaran merupakan bagian dari sumber belajar yang merupakan kombinasi antara perangkat lunak (bahan belajar) dan perangkat keras (alat belajar). Kemudian, menurut Muhson (2010) menyatakan bahwa Secara umum makna media adalah apa saja yang dapat menyalurkan informasi dari sumber Informasi ke penerima informasi. Jadi media pembelajaran merupakan "perangkat lunak" (Software) yang berupa pesan atau informasi pendidikan yang disajikan dengan memakai suatu peralatan bantu (Hardware) agar pesan/informasi tersebut dapat sampai kepada mahasiswa. Di sini jelas bahwa media berbeda dengan peralatan tetapi keduanya merupakan unsur-unsur yang saling terkait satu sama lain dalam usaha menyampaikan pesan/informasi pendidikan kepada mahasiswa. Dengan demikian dapat disimpulkan bahwa (a) media merupakan wadah dari pesan yang oleh sumber atau penyalurnya ingin diteruskan kepada sasaran atau penerima pesan tersebut, dan (b) bahwa materi yang ingin disampaikan adalah pesan pembelajaran, dan bahwa tujuan yang ingin dicapai adalah terjadinya proses belajar.

Menurut Nana dan Surahman, menjelaskan bahwa pengembangan inovasi pembelajaran digital dengan model Blended POE2WE bertujuan untuk (1) mengakses pengetahuan setiap saat tak terbatas waktu dan tempat (2) menjalin komunikasi berbasis internet (3) menciptakan pembelajaran lebih mudah dan menyenangkan. (4) menciptakan proses pembelajaran lebih interaktif dan inovati. Metode penelitian yang digunakan adalah literasi (studi pustaka). Pengolaan Data Elektronik digunakan untuk memanipulasi data menjadi suatu informasi yang lebih berguna. Data merupakan objek mentah, yang belum diolah dan akan diolah. Sedangkan, informasi adalah data yang telah diolah dan sifatnya menjadi data lain yang bermanfaat. Pembelajaran digital adalah produk revolusi industry 4.0. Pembelajaran digital merupakan 'a large collection of computers in networks that are tied together so that many users can share their vast resources'. Selain itu, model pembelajaran Prediction, Observation, Explanation, Elaboration, Write dan Evaluation (POE2WE) dikembangkan dari model pembelajaran POEW dan model pembelajaran Fisika dengan Pendekatan Konstruktivistik. Oleh karena itu, Blended Learning digunakan untuk mensintesis pembelajaran tatap muka dan pembelajaran berbasis online menjadi satu campuran yang terintegrasi sehingga dapat menciptakan dampak yang tinggi, efisien, dan menarik. Secara praktis, blended learning berarti bahwa pembelajaran (pembelajaran tatap muka dalam kelas) juga dilengkapi dengan format elektronik lainnya ( $e$ learning) untuk membuat suatu program pembelajaran yang optimal. Hal ini disebabkan karena pemanfaatan E-Learning sangat diunggulkan dibanding dengan Pembelajaran Konvensional secara tatap muka.

\section{METODE PENELITIAN}

Metode yang digunakan dalam penulisan ini berupa studi kepustakan. Data dikumpulkan untuk dianalisis kemudian disajikan dalam hasil dan pembahasan agar dapat dibuat kesimpulan.

\section{HASIL DAN PEMBAHASAN}

Model pembelajaran POEW dikembangkan dari model pembelajaran Predict, Observe, Explain (POE) dan Think, Bicara, Tulis (TTW). Menurut White and Gystone (Nana, 2014) Model pembelajaran POE adalah 
model pembelajaran dengan proses pengembangan pengetahuan, yang dimulai dengan memprediksi solusi atas suatu masalah, dan kemudian dilanjutkan dengan melakukan percobaan untuk membuktikannya prediksi, dan akhirnya diakhiri dengan menjelaskan hasil percobaan. Strateginya model pembelajaran TTW diperkenalkan oleh Huinker dan Laughlin (1996). Ini terdiri dari tiga fase, yaitu: berpikir, berbicara, dan menulis. Pertama, peserta didik diberi masalah, dan mereka berpikir kemungkinan jawaban untuk masalah tersebut. Kemudian, peserta didik bekerja dalam kelompok untuk mendiskusikan masalah yang ada. Terakhir, peserta didik secara individual menulis hasilnya diskusi mereka dalam kelompok dalam bahasanya sendiri sehingga ia menguasai konsep yang dipelajari. Itu integrasi antara model pembelajaran POE dan model pembelajaran TTW memungkinkan peserta didik untuk aktif dalam proses pembelajaran. Ini memberikan kesempatan kepada peserta didik untuk membangun pengetahuan, untuk berkomunikasi pemikiran, dan untuk menulis hasil diskusi mereka sehingga peserta didik jauh lebih menguasai konsep yang akan mempengaruhi peningkatan hasil belajar. Penerapan model pembelajaran POEW yang berlaku masih kurang mengoptimalkan kemampuan siswa untuk memprediksi dan untuk memecahkan masalah yang diberikan. Kurangnya pengetahuan awal siswa menjadi kendala bagi pembentukan prediksi mereka. Prediksi yang dibuat oleh seorang siswa membutuhkan pengetahuan awal dan luas tentang suatu masalah. Selain, selama praktikum para siswa hanya memainkan peran mereka dalam pelaksanaan praktikum. Instrumen, bahan, dan ukuran percobaan disediakan oleh para guru. Hal ini membuat siswa tidak terlatih untuk memilikinya pemikiran kritis untuk merancang eksperimennya sendiri berdasarkan prediksi yang ia buat (Nana, 2014). Karena itu diperlukan untuk mengembangkan memprediksi, mengamati, menjelaskan, menguraikan, dan menulis (POE2WE) model pembelajaran, yang merupakan kolaborasi antara model pembelajaran POEW dan model konstruktivis. Model kolaboratif dapat memungkinkan siswa untuk membuat prediksi berdasarkan pengetahuan awal yang mereka miliki sehingga mereka dapat memecahkan masalah yang diberikan oleh guru mereka atau yang mereka temui dalam kehidupan sehari-hari mereka. Selain itu, para siswa diharapkan untuk menerapkannya dalam kehidupan sehari-hari mereka.

Model pembelajaran Prediction, Observation, Explanation, Elaboration, Write dan Evaluation (POE2WE) dikembangkan dari model pembelajaran POEW dan model pembelajaran Fisika dengan Pendekatan Konstruktivistik. Menurut Nana (2018) Model POE2WE merupakan model pembelajaran yang dikembangkan untuk mengetahui pemahaman siswa mengenai suatu konsep dengan pendekatan konstruktivistik. Model ini membangun pengetahuan dengan urutan proses terlebih dahulu meramalkan atau memprediksi solusi dari permasalahan, melakukan eksperimen untuk membuktikan prediksi, kemudian menjelaskan hasil eksperimen yang diperoleh secara lisan maupun tertulis, membuat contoh penerapan dalam kehidupan sehari-hari, menuliskan hasil diskusi dan membuat evaluasi tentang pemahaman siswa baik secara lisan maupun tertulis.

Model pembelajaran POE2WE dapat menjadikan siswa sebagai subjek di dalam pembelajaran. Siswa aktif dalam menemukan suatu konsep melalui pengamatan atau eksperimen secara langsung, bukan dari menghafal buku materi maupun penjelasan dari 
guru. Model ini memungkinkan siswa aktif dalam proses pembelajaran, memberikan kesempatan kepada siswa untuk mengkonstrukssi pengetahuannya, mengkomunikasikan pemikirannya dan menuliskan hasil diskusinya sehingga siswa lebih menguasai dan memahami konsep yang akan berdampak pada peningkatan prestasi belajar siswa. Hal tersebut sesuai dengan pendapat Permatasari (Nana, 2018) bahma model ini memberikan kesempatan kepada siswa untuk mengkonstruksi pengetahuannya sendiri, melakukan pengamatan terhadap fenomena serta mengkomunikasikan pemikiran dan hasil diskusi sehingga siswa akan lebih mudah menguasai konsep yang di ajarkan.

Penggabungan tahapan-tahapan pembelajaran model POEW dengan Pendekatan Konstruktivistik maka dapat di susun langkahlangkah pembelajaran model POE2WE. Menurut Nana, dkk (2014) secara terinci langkah-langkah atau sintaks pembelajaran model POE2WE sebagai berikut: a) Prediction, tahap prediction yaitu siswa membuat prediksi atau dugaan awal terhadap suatu permasalahan. Permasalahan yang ditemukan berasal dari pertanyaan dan gambar oleh guru yang ada di LKS/buku siswa sebelum siswa membuat prediksi. Pembuatan prediksi jawaban tahap Prediction pada model POEW identik dengan fase Engagenent pada pendekatan konstruktivistik. Guru mengajukan pertanyaan yang dapat mendorong siswa untuk dapat membuat prediksi atau jawaban sementara dari suatu permasalahan. b) Observation tahap observation yaitu untuk membuktikan prediksi yang telah di buat oleh siswa. Siswa diajak melakukan eksperimen berkaitan dengan masalah atau persoalan yang di temukan. Selanjutnya siswa mengamati apa yang terjadi, kemudian siswa menguji kebenaran dari dugaan sementara yang telah dibuat. Tahap Observation pada model POEW identik dengan fase Exploration pada pendekatan konstruktivistik. c) Explanation, tahap explanation atau menjelaskan yaitu siswa memberikan penjelasan terhadap hasil eksperimen yang telah dilakukan. Penjelasan dari siswa dilakukan melalui diskusi dengan anggota kelompok kemudian tiap kelompok mempresentasikan hasil diskusinya di depan kelas. Jika prediksi yang di buat siswa ternyata terjadi di dalam eksperimen, maka guru membimbing siswa merangkum dan memberi penjelasan untuk menguatkan hasil eksperimen yang dilakukan. Namun jika prediksi siswa tidak terjadi dalam eksperimen, maka guru membantu siswa mencari penjelasan mengapa prediksi atau dugaannya tidak benar. Tahap explanation identik dengan fase explanation pada pendekatan konstuktivistik. d) Elaboration, tahap elaboration yaitu siswa membuat contoh atau menerapkan konsep dalam kehidupan sehari-hari. Tahap elaboration di ambil dari pendekatan konstruktivistik. Tahap ini guru medorong siswa untuk menerapkan konsep baru dalam situasi baru sehingga siswa lebih memahami konsep yang di ajarkan guru. Tahap ini pengembangan dari pendekatan konstruktivistik. e) Write, tahap write atau menulis yaitu melakukan komunikasi secara tertulis,merefleksikan pengetahuan dan gagasan yang dimiliki siswa. Siswa menuliskan hasil diskusi dan menjawab pertanyaan yang ada pada LKS. Selain itu pada tahap write ini, siswa membuat kesimpulan dan laporan dari hasil eksperimen. Tahap ini merupakan pengembangan dari model TTW. f) Evaluation, tahap evaluation yaitu evaluasi terhadap pengetahuan, keterampilan dan perubahan proses berfikir siswa. Pada tahap ini siswa di evaluasi berupa lisan maupun tulisan.Tahap ini merupakan pengembangan dari pendekatan konstruktivistik. 
Tabel 1. Kegiatan Pembelajaran Model Pembelajaran Model POE2WE

\section{Fase- Kegiatan Guru Kegiatan fase \\ Peserta Didik}

\begin{tabular}{|c|c|c|}
\hline Prediction & $\begin{array}{l}\text { - } \\
\text { Menyampaikan } \\
\text { tujuan } \\
\text { pembelajaran. } \\
\text {-Mengajukan } \\
\text { pertanyaan } \\
\text { kepada siswa } \\
\text { - } \\
\text { Menginventaris } \\
\text { ir prediksi dan } \\
\text { alasan yang di } \\
\text { kemukakan } \\
\text { peserta didik. }\end{array}$ & $\begin{array}{l}\text {-Memperhatikan } \\
\text { penjelasan dari } \\
\text { guru. } \\
\text {-Memprediksi } \\
\text { jawaban } \\
\text { pertanyaan dari } \\
\text { guru - } \\
\text { Mendiskusikan } \\
\text { hasil prediksinya }\end{array}$ \\
\hline $\begin{array}{l}\text { Observatio } \\
n\end{array}$ & $\begin{array}{l}\text {-Mendorong } \\
\text { peserta didik } \\
\text { untuk bekerja } \\
\text { secara } \\
\text { kelompok - } \\
\text { Membagikan } \\
\text { LKS - } \\
\text { Mengawasi } \\
\text { kegiatan } \\
\text { percobaan } \\
\text { yangdilakukan } \\
\text { oleh peserta } \\
\text { didi }\end{array}$ & $\begin{array}{l}\text { - Membentuk } \\
\text { kelompok } \\
\text { - Melakukan } \\
\text { percobaan } \\
\text { - Mengumpulkan } \\
\text { data hasil } \\
\text { percobaan } \\
\text { - Melakukan } \\
\text { diskusi } \\
\text { kelompok } \\
\text { - Menyimpulkan } \\
\text { hasil percobaan }\end{array}$ \\
\hline $\begin{array}{l}\text { Explanatio } \\
n\end{array}$ & $\begin{array}{l}\text {-Mendorong } \\
\text { peserta didik } \\
\text { untuk } \\
\text { menjelaskan } \\
\text { hasil percobaan. }\end{array}$ & $\begin{array}{l}\text {-Mengemukakan } \\
\text { pendapatnya } \\
\text { tentang hasil } \\
\text { percobaan }\end{array}$ \\
\hline
\end{tabular}

\begin{tabular}{|c|c|c|}
\hline & $\begin{array}{l}\text {-Meminta } \\
\text { peserta didik } \\
\text { pempresentasik } \\
\text { an hasil } \\
\text { percobaannya } \\
\text { - } \\
\text { Mengklarifikasi } \\
\text { kan hasil } \\
\text { percobaannya - } \\
\text { Menjelaskan } \\
\text { konsep/definisi } \\
\text { baru }\end{array}$ & $\begin{array}{l}\text { Mengemukakan } \\
\text { pendapatnya } \\
\text { tentang gagasan } \\
\text { baru berdasarkan } \\
\text { hasil percobaan. } \\
\text {-Menanggapi } \\
\text { presentasi dari } \\
\text { kelompok lain. } \\
\text {-Konsep baru } \\
\text { dari guru dapat } \\
\text { di terima }\end{array}$ \\
\hline $\begin{array}{l}\text { Elaboratio } \\
n\end{array}$ & $\begin{array}{l}\text {-Memberi } \\
\text { permasalahan } \\
\text { berkaitan } \\
\text { dengan } \\
\text { penerapan } \\
\text { konsep. } \\
\text {-Mendorong } \\
\text { peserta didik } \\
\text { untuk } \\
\text { menerapkan } \\
\text { konsep baru } \\
\text { dalam situasi } \\
\text { baru. }\end{array}$ & $\begin{array}{l}\text {-Menerapkan } \\
\text { konsep baru } \\
\text { dalam situasi } \\
\text { baru atau } \\
\text { kehidupan } \\
\text { sehari-hari. }\end{array}$ \\
\hline Write & $\begin{array}{l}\text { - Memberi } \\
\text { kesempatan } \\
\text { kepada peserta } \\
\text { didik untuk } \\
\text { mencatat }\end{array}$ & $\begin{array}{l}\text {-Mencatat hasil } \\
\text { penjelasan dari } \\
\text { guru dan diskusi } \\
\text { kelompok }\end{array}$ \\
\hline Evaluation & $\begin{array}{l}\text {-Mengajukan } \\
\text { pertanyaan } \\
\text { untuk penilaian } \\
\text { proses } \\
\text {-Menilai } \\
\text { pengetahuan }\end{array}$ & $\begin{array}{l}\text {-Menjawab } \\
\text { pertanyaan } \\
\text { berdasarkan data } \\
\text { - } \\
\text { Mendemonstrasi } \\
\text { kan kemampuan }\end{array}$ \\
\hline
\end{tabular}




\begin{tabular}{l|l|l}
\hline peserta didik & dalam \\
penguasaan \\
-Memberikan & konsep \\
balikan & \\
terhadap & jawaban peserta \\
did & \\
&
\end{tabular}

(Sumber : Nana, dkk, 2018)

Menurut Nana dan Surahman, menjelaskan bahwa pada era digital atau era informasi sekarang ini ilmu pengetahuan dan teknologi berkembang dengan pesat. Perkembangan ini memiliki dampak semakin terbuka dan tersebarnya informasi dan pengetahuan dari dan ke seluruh dunia menembus batas jarak,tempat, ruang dan waktu. Kenyataannya dalam kehidupan manusia di era digital ini akanselalu berhubungan dengan teknologi. Teknologi pada hakikatnya adalah proses untukmendapatkan nilai tambah dari produk yang dihasilkannya agar bermanfaat. Teknologi telahmempengaruhi dan mengubah manusia dalam kehidupannya sehari-hari, sehingga jikasekarang ini 'gagap teknologi' maka akan terlambat dalam menguasai informasi, dan akan tertinggal pula untuk memperoleh berbagai kesempatan maju. Informasi memiliki peranpenting dan nyata, pada era masyarakat informasi (information society) atau masyarakat ilmupengetahuan (knowledge society).

Menurut Nana dan Surahman, menjelaskan bahwa Aplikasi teknologi informasi dan komunikasi yang merupakan pengembangan teknologi, diantaranya adalah media komputer. Komputer merupakan alat dan aplikasi teknologiberbasis informasi dan komunikasi yang dimanfaatkan sebagai perangkat utama untukmengolah data menjadi informasi yang bermanfaat dengan memproses, menyajikan, danmengelola informasi. Pengolahan data dengan komputer disebut dengan Pengolaan Data Elektronik (Electronic Data Processing $E D P)$.

Menurut Nana dan Surahman, menjelaskan Penggabungan tahapan-tahapan pembelajaran model POEW dan model pembelajaran Fisika dengan Pendekatan Konstruktivistik maka dapat di susun langkahlangkah pembelajaran model POE2WE secara terinci sebagai berikut:

\section{a) Prediction}

Tahap prediction yaitu peserta didik membuat prediksi atau dugaan awal terhadap suatupermasalahan. Permasalahan yang ditemukan berasal dari pertanyaan dan gambar tentangmateri yang disampaikan oleh guru yang ada di Lembar Kerja peserta didik (LKS)/buku peserta didik sebelum peserta didik membuat prediksi. Pembuatan prediksi jawaban tahap Prediction pada model POEW identik dengan fase Engagenent pada pendekatankonstruktivistik. Guru mengajukan pertanyaan yang dapat mendorong peserta didik untukdapat membuat prediksi atau jawaban sementara dari suatu permasalahan.

\section{b) Observation}

Tahap Observation yaitu untuk membuktikan prediksi yang telah di buat oleh peseradidik. Peserta didik diajak melakukan eksperimen berkaitan dengan masalah ataupersoalan yang di temukan. Selanjutnya peserta didik mengamati apa yang terjadi, kemudian peserta didik menguji kebenaran dari dugaan sementara yang telah dibuat. Tahap Observation pada model POEW identik dengan fase Exploration pada pendekatan konstruktivistik. 


\section{c) Explanation}

Tahap Explanation atau menjelaskan yaitu peserta didik memberikan penjelasan terhadaphasil eksperimen yang telah dilakukan. Penjelasan dari peserta didik dilakukan melaluidiskusi dengan anggota kelompok kemudian tiap kelompok mempresentasikan hasil diskusinya di depan kelas. Jika prediksi yang di buat peserta didik ternyata terjadi didalam eksperimen, maka guru membimbing peserta didik merangkum dan memberi penjelasan untuk menguatkan hasil eksperimen yang dilakukan. Namun jika prediksipeserta didik tidak terjadi dalam eksperimen, maka guru membantu peserta didik mencari penjelasan mengapa prediksi atau dugaannya tidak benar. Tahap explanation identik dengan fase explanation pada pendekatan konstuktivistik.

\section{d) Elaboration}

Tahap elaboration yaitu peserta didik membuat contoh atau menerapkan konsep dalam kehidupan sehari-hari. Tahap elaboration di ambil dari pendekatan konstruktivistik. Tahap ini guru medorong peserta didik untuk menerapkan konsep baru dalam situasi baru sehingga peserta didik lebih memahami konsep yang di ajarkan guru. Tahap ini pengembangan dari pendekatan konstruktivistik.

\section{e) Write}

Tahap write atau menulis yaitu melakukan komunikasi secara tertulis, merefleksikan pengetahuan dan gagasan yang dimiliki peserta didik Menurut Masingilia dan Wisniowska (1996) dalam (Yamin \& Ansari, 2012) menulis dapat membantu pesertadidik untuk mengekspresikan pengetahuan dan gagasan mereka. peserta didik menuliskan hasil diskusi dan menjawab pertanyaan yang ada pada LKS. Selain itu pada tahap write ini, peserta didik membuat kesimpulan dan laporan dari hasil eksperimen. Tahap ini merupakan pengembangan dari model TTW.

\section{f) Evaluation}

Tahap Evaluation yaitu evaluasi terhadap pengetahuan, keterampilan dan perubahan proses berfikir peserta didik. Pada tahap ini peserta didik di evaluasi tentang materi gerak lurus berupa lisan maupun tulisan. Tahap ini merupakan pengembangan dari pendekatan konstruktivistik.

Menurut Nana dan Surahman, Blended POE2WE kerangka teori POE2WE ini dibangun berdasarkan pandangan dari beberapa teori yang mengkerangkai model pembelajaran POE2WE. Dalam POE2WE dipadukan tiga jenis interaksi yang meliputi interaksi sosial, inetraksi muatan, dan interaksi dosen. Penjelasan adalah berikut:

a. Tipe interaksi pertama adalah dengan dosen yang menjadi fasilitasor active learning dan interaksi tatap muka yang terjadi pada suatu setting sosial. Akan tetapi dosenlah yang merancang dan mengelola urut-urutan pembelajaran dan menyeleksi media yang tepat sebelum berinteraksi dengan mahasiswa. Selanjutnya dosen menggunakan e-learning www.unsil.ac.id untuk meakukan pembelajaran jarak jauh dan pengumpulan tugas serta komunikasi secara online. Mahasiswa dapat berdiskusi dengan mahasiswa lain dan dengan mahasiswa dapat berdiskusi dengan mahasiswa lainnya dengan dosen pada waktu yang bersamaan sehingga akan terjadi komunikasi interpersonal dan feedback.

b. Interaksi kedua adalah dengan muatan interaksi ini menjembatani interaksi kognitif dengan konsep konsep dan keterampilan yang termuat dalam modul pembelajaran. Modul tersebut disertai dengan petunjuk penggunaan 
dan mind mapping setap topik sehingga tujuan pembelajaran tergambara dengan jelas.

c. Terakhir, interaksi sosial dimaksudkan senbagai kemampuan pembelajar (siswa) untuk mempersepsikan diri mereka sebagai sebuah komunitas yang saling bergantung secara positif (positive interdependent, cooperation). Interaksi yang demikian itu dapat terjadi di keseluruhan proses pembelajaran karena mereka engerjakan tgas-tugasyang menuntut kerjasama. Sebagaimana diketahui dimensi interaksi (diskursus social). Makna ini kemudian dibagai diantara anggota-anggota kelompok yang ikut membangun pengetahuan bersama melalui tanggapan antar mereka sendiri. Ini sudah merupakan pencapaian level kognitif yang tinggi (Aviv, 2000).

Menurut Nana dan Surahman, menjelaskan bahwa pengembangan inovasi pembelajaran blended learning dalam pembelajaran Fisika dengan model POE2WE dikategorikan sebagai hal baru. Pengembangan model ini lebih menyentuh ranah e-learning sebagai jawaban atas tuntutan revolusi industry 4.0. Akan tetapi, inovasi pembelajaran ini masih dalam tahap pengembangan dan masih perlu perbaikan atau peningkatan dari berbagai aspek.

Menurut Muhson (2010) menjelaskan bahwa di era globalisasi dan informasi ini penggunaan media pembelajaran berbasis Teknologi Informasi (TI) menjadi sebuah kebutuhan dan tuntutan namun dalam implementasinya bukanlah merupakan hal yang mudah. Dalam menggunakan media tersebut harus memperhatikan beberapa teknik agar media yang dipergunakan itu dapat dimanfaatkan dengan maksimal dan tidak menyimpang dari tujuan media tersebut.
Menurut Shohibun, dkk (2017) menjelaskan Saat ini, virtual class sudah mulai dijadikan alternatif pembelajaran. Hal ini dikarenakan pembelajaran ini tidak lagi terikat oleh ruang dan waktu. Akan tetepi, virtual class tidak serta merta menggantikan perkuliahan konvensional karena masing-masing mempunyai kelebihan dan kekurangan. Namun, dalam hal ini virtual class diharapkan menjadi penunjang proses pembelajaran dikelas secara konvensional, apa yang tidak tersampaikan di kelas konvensional dapat disampaikan melalui virtual class. Berdasarkan uraian di atas, tujuan penelitian ini yaitu mengembangkan inovasi $e$ learning untuk menghasilkan produk media pembelajaran Virtual Class. Pembelajarn tersebut dipadukan dengan bantuan Google Drive sebagai sarana penunjang perkuliahan di Prodi Pendidikan Fisika Universitas Pasir Pengaraian (UPP). Capaian dari penelitian ini adalah pembelajaran Virtual Class berbantuan Google Drive yang efektif sebagai sarana penunjang perkuliahan mahasiswa Prodi Pendidikan Fisika UPP.

Memang, Google Drive sebagai platform penyimpanan data dan dokumen berbasis online ini sudah selayaknya diterapkan dalam dunia pendidikan, terutama dalam pembelajaran Fisika. Kesesuaian antara Google Drive dengan Model Blended POE2WE ini memang sudah sesuai.

Tabel 2. Pembelajaran Fisika menggunakan Google Drive dengan Model Blended POE2WE

Prediction

$\begin{array}{lrr}\text { Guru menyajikan } & \text { data } \\ \text { melalui } & \text { gambar atau video } \\ \text { yang disimpan } & \text { dan } \\ \text { disebarkan melalui } & \text { Google } \\ \text { Drive, sehingga } & \text { mampu } \\ \text { menyimpan kapasitas gambar } & \text { gamban } \\ \text { dan foto yang lebih banyak, }\end{array}$


dibanding media yang lain.

\begin{tabular}{|l|l|}
\hline Observation & $\begin{array}{l}\text { Guru memberikan perintah } \\
\text { kepada peserta didik untuk } \\
\text { mengobservasi sesuai dengan } \\
\text { materi dan modul yang } \\
\text { diberikan oleh guru melalui } \\
\text { Google Drive. }\end{array}$ \\
\hline Explanation & $\begin{array}{l}\text { Peserta didik menjelaskan } \\
\text { hasil prediksi dan observasi } \\
\text { dengan cara di video, foto, } \\
\text { audio dan sebagainya lalu } \\
\text { dikirim ke Google Drive } \\
\text { guru, sehingga guru bisa } \\
\text { menilai dari jarak jauh. }\end{array}$ \\
\hline Elaboration & $\begin{array}{l}\text { Guru mengaitkan materi } \\
\text { dengan kehidupan sehari-hari } \\
\text { lewat beberapa dokumen dan } \\
\text { data-data dari Google Drive }\end{array}$ \\
\hline Write & $\begin{array}{l}\text { Peserta didik mencatat poin- } \\
\text { poin penting, hasil dari } \\
\text { mnyimak materi dan } \\
\text { sebagainya di dokumen dan } \\
\text { data-data, baik itu foto, } \\
\text { gambar dan sebagainya di } \\
\text { Google Drive. Menulis bisa } \\
\text { secara manual ataupun } \\
\text { virtual. }\end{array}$ \\
\hline $\begin{array}{l}\text { Guru memberikan soal-soal } \\
\text { latihan kepada peserta didik } \\
\text { secara interaktif dan otomatis } \\
\text { melalui Google Drive. }\end{array}$ \\
\hline Evalion
\end{tabular}

Dari Tabel 2. Diatas menunjukkan bahwasannya, keefektifan Google Drive sebagai media pembelajaran Fisika, bagus untuk diterapkan di dalam proses belajar mengajar. Apalagi, bagi guru yang mempunyai kesibukan yang padat dan sering keluar kota, maka perlu menggunakan Google Drive untuk menunjang pembelajaran, supaya kegiatan belajar mengjara tetap berjalan walaupun dengan jarak jauh. Inilah kesetimbangan antara perkembangan zaman dengan keilmuan.

\section{KESIMPULAN}

Dapat diberi kesimpulan hasil dari studi pustaka terkait Penerapan Google Drive sebagai Media Pembelajaran Fisika menggunakan Model Blended POE2WE ini adalah sebagai berikut.

1. Pemanfaatan Google Drive sebagai media pembelajaran Fisika ini sangatlah baik, apalagi bila diterapkan dengan menggunakan model Blended POE2WE.

2. Keefektifan Google Drive dalam pembelajaran jarak jauh ini sangatlah mebantu bagi guru dan peserta didik yang mempunyai kendala atau berada dalam berbagai kesibukan, apalagi guru yang sering keluar kota dalam tugas negara. Sehingga, Google Drive ini sangatlah efektif dan efisien.

\section{DAFTAR PUSTAKA}

Alfian, I. (2019). Pengembangan Media Scrapbook Pembelajaran Tematik Tema 6 Merawat Hewan Dan Tumbuhan Subtema 1 Hewan Di Sekitar Pada Kelas 2 Sekolah Dasar (Doctoral dissertation, University of Muhammadiyah Malang).

Cahyono, G. H. (2013). MENGGUNAKAN GOOGLE DRIVE. Swara Patra, 3(1).

Djamaluddin, A. (2017). FILSAFAT PENDIDIKAN (Educational Phylosophy). Istiqra, 1(2), 150-156. 
Muhson, A. (2010). Pengembangan media pembelajaran berbasis teknologi informasi. Jurnal Pendidikan Akuntansi Indonesia, 8(2).

Nana, \& Rochsantiningsih, Dewi \& Muhammadakhyar, \& Sajidan,. (2016). The Effectiveness of Scientific Approach Through Predict, Observe, Explain, Elaborate, Write and Evaluate (POE2WE) Model on the Topic of Kinematics (Rectilinear Motion) at Senior High School. Social Sciences (Pakistan). 11. 1028-1034.

Nana, N., \& Surahman, E. (2019). Pengembangan Inovasi Pembelajaran Digital Menggunakan Model Blended POE2WE di Era Revolusi Industri 4.0. Prosiding SNFA (Seminar Nasional Fisika dan Aplikasinya), 4, 82-90. doi:http://dx.doi.org/10.20961/prosidingsnf a.v4i0.35915

Nana, S., Akhyar, M., \& Rochsantiningsih, D. (2014). The Development Of Predict, Observe, Explain, Elaborate, Write, And Evaluate (POE2WE) Learning Model In Physics Learning At Senior Secondary School. Development, 5(19).

Nana, Sajidan, Akhyar, M., \& Rochsantiningsih, D. (2014). The Development Of Predict, Observe, Explain, Elaborate, Write, and Evaluate (POE2WE) Learning Model in Physics Learning At Senior Secondary School. Journal of

Education and Practice, 5 (19): 57-60.

Sohibun, A. F. Y., \& Ade, F. Y. (2017). Pengembangan Media Pembelajaran Berbasis Virtual Class Berbantuan Google Drive'. Tadris: Jurnal Keguruan Dan Ilmu
TarbiyahJurnal Keguruan Dan Ilmu Tarbiyah, 2. 